\title{
TRIAXIAL TESTING OF FROZEN SAND
}

\author{
By V. R. PARAmeswaran \\ (Division of Building Research, National Research Council of Canada, Ottawa, Ontario \\ KIA oR6, Canada) \\ and S. J. Jones \\ (Glaciology Division, Department of Environment, Ottawa, Ontario $\mathrm{K}_{\mathrm{IA}}$ oE7, Canada)
}

\begin{abstract}
Triaxial testing of frozen saturated Ottawa sand under confined compression was carried out under hydrostatic pressures varying between 0.1 and $75 \mathrm{MPa}$ at a temperature of $-10^{\circ} \mathrm{C}$ and strain-rate $7.7 \times 10^{-5} \mathrm{~s}^{-1}$. Yield and failure stresses increased with increasing hydrostatic pressures up to about $40 \mathrm{MPa}$, beyond which the stresses dropped. The results are analysed according to the Mohr-Coulomb failure criterion and compared with past results in the literature.

RÉsumé. Essai triaxial sur un sable gelé. Un essai triaxial de compression avec étreinte latérale sur un sable saturé et gelé d’Ottawa a été effectué sous des pressions hydrostatiques variant de o, I à $75 \mathrm{MPa}$ à une température de $-10^{\circ} \mathrm{C}$ et une vitesse de déformation de $7,7 \times 10^{-5} \mathrm{~s}^{-1}$. Les contraintes d'écoulement et de rupture ont augmenté lorsque les pressions hydrostatiques ont été augmentées jusqu'à environ $40 \mathrm{MPa}$, au delà desquelles les contraintes diminuèrent. Les résultats sont analysés selon le critère de rupture MohrCoulomb et comparés avec les résultats déjà obtenus se trouvant dans la documentation.

Zusammenfassung. Dreiachsige Versuche mit gefrorenem Sand. Unter hydrostatischem Druck zwischen o, I und $75 \mathrm{MPa}$ bei einer Temperatur von $-10^{\circ} \mathrm{C}$ und einer Verformungsrate von $7,7 \times 10^{-5} \mathrm{~s}^{-1}$ wurden dreiachsige Versuche an gefrorenem, gesättigtem Ottawa-Sand vorgenommen. Die Nachgeb- und Bruchspannungen nahmen mit dem Anwachsen des hydrostatischen Druckes bis etwa $40 \mathrm{MPa}$ zu; danach fielen sie ab. Die Ergebnisse werden mit dem Bruchkriterium von Mohr-Coulomb analysiert und mit früheren Ergebnissen aus der Literatur verglichen.
\end{abstract}

\section{INTRODUCTION}

Development and utilization of natural resources in Arctic regions have brought about increased interest in cold regions science and technology. In North America and the Soviet Union development of the permafrost regions is advancing rapidly and engineering design and construction principles have to be formulated that will ensure structural and environmental stability. For the design of foundations for stable structures in permafrost areas a knowledge of the strength and deformation characteristics of frozen soils is essential.

The mechanical behaviour of frozen soil specimens is governed by the intrinsic material properties such as moisture content, air bubbles, salts, organic matter, and grain size, and by externally imposed testing conditions such as strain-rate, temperature, stress and strain history, and confining pressure. Several authors (Andersland and Akili, r967; Goughnour and Andersland, 1968; Andersland and AlNouri, 1970; Kaplar, 1971; Perkins and Ruedrich, I973; Ruedrich and Perkins, 1974; Parameswaran, 1980) have studied the strength and deformation behaviour of various frozen soils under different conditions of temperature and strain-rate. Besides these, the Proceedings of three International Conferences on Permafrost (Lafayette, Indiana, U.S.A., I966; Yakutsk, U.S.S.R., I973 and Edmonton, Canada, I978) ([Permafrost], [1966], 1973, 1978) contain papers on the mechanical properties of some frozen soils. Very few studies, however, have been reported on the mechanical properties of frozen soils under confined conditions.

Chamberlain and others (1972) tested two ice-saturated soils under confined pressures of up to $280 \mathrm{MPa}$ at $-10^{\circ} \mathrm{C}$ and reported an initial yield point on soil samples similar to that observed in carbon steels. They interpreted the further increase in strength with strain as due to mobilization of friction and interlocking of sand particles. Sayles (1974) tested cylindrical sand samples under confined pressures of up to $8.2 \mathrm{MPa}$ at $-3.85^{\circ} \mathrm{C}$ for strainrates varying between $3.33 \times 10^{-5}$ and $1.67 \times 10^{-2} \mathrm{~s}^{-1}$. He found that the shear strength of 
saturated sand increased with increasing confining pressure. Alkire and Andersland (1973) tested saturated sand specimens at $-12^{\circ} \mathrm{C}$ under pressures of up to $7 \mathrm{MPa}$ at a rate of $4.43 \times \mathrm{IO}^{-5} \mathrm{~s}^{-1}$, and concluded that mechanical properties of frozen silica sand under confined conditions depend on cohesion of the ice matrix and sliding friction, particle reorientation, and dilatancy effects of sand grains. They also found that creep-rates decreased exponentially and creep strength increased with any increase in confining pressure.

All these investigations showed that the mechanical behaviour of frozen soils is governed by the flow of ice in the early stages of the deformation process (up to r \% axial strain) and by interparticle friction at the later stages of deformation. Some work has been carried out on the effect of confining pressure on the behaviour of ice. Recently Jones (1978) has observed that the yield stress for polycrystalline ice increases initially with increasing confining pressures of up to $30 \mathrm{MPa}$; and that beyond this the yield stress decreases for further increase in hydrostatic pressure. The initial increase is thought to be due to the elimination of cracking and brittle failure by the confining pressure, thereby allowing the ice to deform plastically.

In the present work the behaviour of saturated frozen Ottawa sand of uniform grain-size was observed under a combination of uniaxial compression and hydrostatic pressure and compared with the behaviour of ice under similar conditions. This will be helpful in understanding the behaviour of the debris-laden ice at the bottom of glaciers, since it controls the sliding of glaciers on their beds.

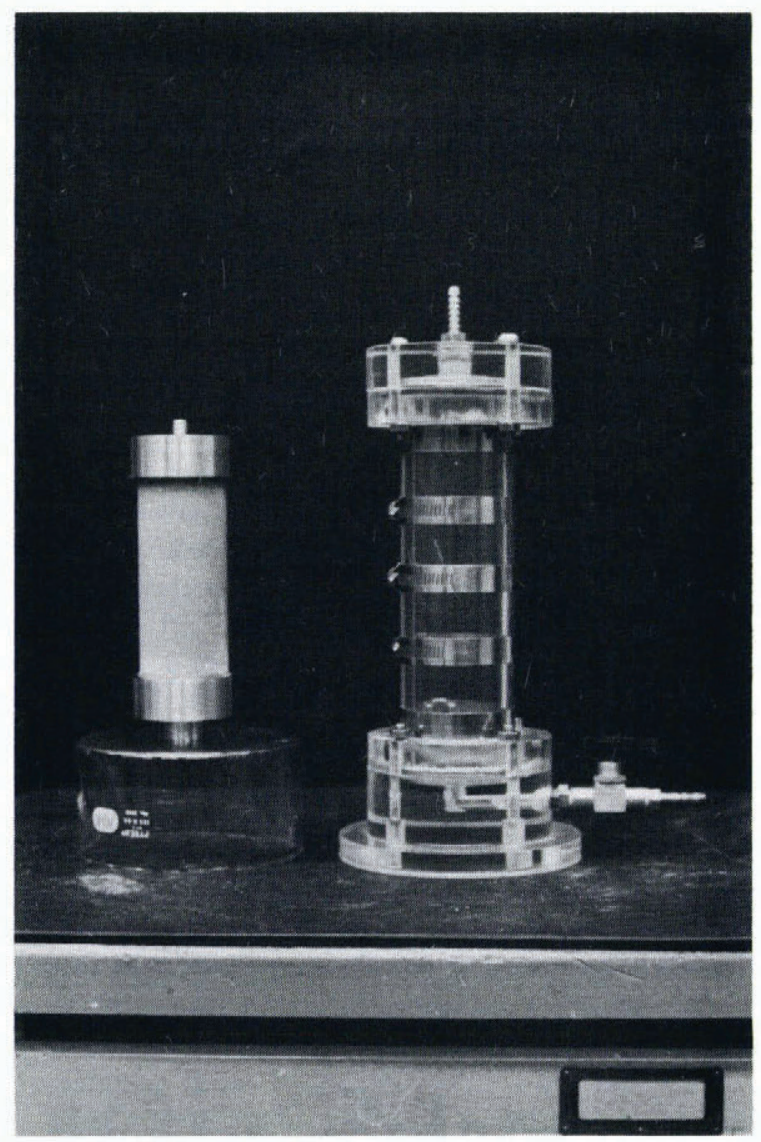

Fig. I. Split "Plexiglass" mould and finished test specimen. 
EXPERIMENTAL PROCEDURE

\section{Sample preparation}

The sand used for preparing the test specimens was obtained from Ottawa, Illinois (ASTM specification C-rog, passing sieve No. 30 and retained on sieve No. roo) with grain size between 0.2 and $0.6 \mathrm{~mm}$. When mixed thoroughly with $14 \%$ water by weight and compacted, this sand had an optimum dry density of $\mathrm{I} 700 \mathrm{~kg} \mathrm{~m}^{-3}\left(\mathrm{I} 06 \mathrm{lb} \mathrm{ft}^{-3}\right)$ as determined by a standard Proctor test. Cylindrical samples of frozen sand having diameter $D$ of $50.8 \mathrm{~mm}$ were prepared in a split "Plexiglass" (polymethyl methacrylate) mould (Fig. I) in which the sand was compacted in layers at the optimum moisture content. The mould was then closed and evacuated to remove air from the voids. After the sand was saturated with de-aerated distilled water, the top cover was removed and the mould transferred to an insulated box containing vermiculite inside a cold room at $-6^{\circ} \mathrm{C}$. The specimen in the mould was allowed to freeze uniaxially. The water expelled during freezing was removed from the bottom through a capillary tube containing a heater wire. For details of specimen preparation see Baker (1976).

After freezing (which took about $60 \mathrm{~h}$ ) the specimen was slipped from the mould and about $20 \mathrm{~mm}$ cut from the top exposed during freezing. The ends were trimmed and faced in a lathe inside the cold room and stainless steel end caps were mounted on them using distilled water as bonding material. The finished test specimens had a gauge length $L$ of about $108 \mathrm{~mm}$ between end caps (so that the $L / D$ ratio was greater than 2) and a total moisture content of about $20 \%$ by weight. Figure I shows a mould and a finished test specimen with end caps.

\section{Test procedure}

The cylindrical frozen sand specimens were tested in a high-pressure cell (a schematic diagram is shown in Fig. 2). The pressure vessel was kept inside a cold box (maintained at $-\mathrm{IO} \pm \mathrm{I}^{\circ} \mathrm{C}$ ) on the base of a Model i 1 i 6 Instron universal testing machine of $25000 \mathrm{~kg}$ capacity. Most of the tests were carried out at a constant strain-rate of about $7.7 \times 10^{-5} \mathrm{~s}^{-1}$.

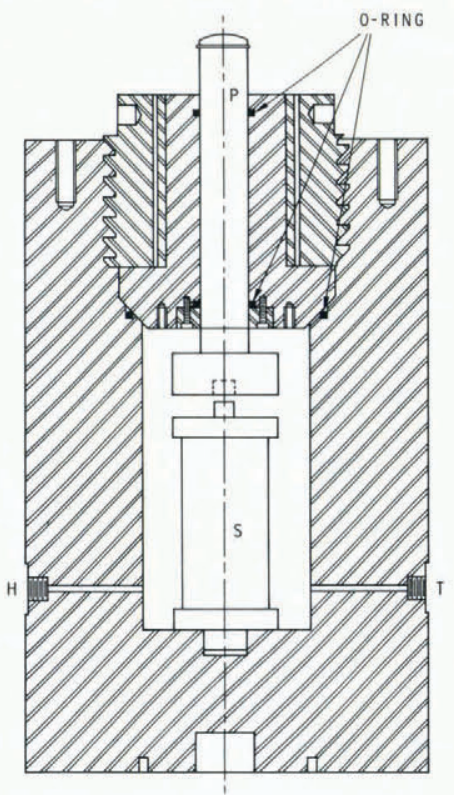

Fig. 2. Schematic diagram of high-pressure cell. 
The hydrostatic confining pressure was varied for each test. The pressurizing fluid was Dow Corning silicone fluid 200. Uniaxial compressive force was applied by a piston $\mathrm{P}$ sealed by two O-rings. Details of the test procedure have been given by Jones (1978). Tests were done at pressures varying between $0 . \mathrm{I} \mathrm{MPa}$ (atmospheric pressure) and $76 \mathrm{MPa}$ ( 14.5 to I I 000 $\mathrm{lb}$ in $\left.^{-2}\right)$.

\section{Results}

Figure 3 shows the stress-strain curves obtained under various confining pressures for specimens tested at $-10 \pm 0.6^{\circ} \mathrm{C}$ at a strain-rate of $7.7 \times 1 \mathrm{O}^{-5} \mathrm{~s}^{-1}$. The following observations were made:

I. Specimens deformed (mostly) elastically* for strains less than I\%. At low hydrostatic pressures (Fig. 3a) a sharp yield point and a yield drop were observed at the end of the elastic region. As confining pressure increased, the yield drop was suppressed (Fig. $3 \mathrm{~b})$; and for high confining pressures $(>20 \mathrm{MPa})$ the transition from the elastic to the plastic region was smooth (Fig. 3c).

2. Yield stress $\sigma_{\mathrm{y}}$ was found to increase with increasing hydrostatic pressure up to about $34 \mathrm{MPa}$ beyond which it decreased with further increase in pressure. Figure 4 shows the variation of yield stress with hydrostatic pressure.

3. The failure strength $\sigma_{\max }$ (i.e. the maximum deviatoric stress, $\sigma_{1}-\sigma_{3}$ ) increased with increasing hydrostatic pressure. Table I shows the values of the yield stress $\sigma_{\mathbf{y}}$ and deviatoric stress $\sigma_{1}-\sigma_{3}$ measured for various specimens. Figure 4 shows the deviatoric stress $\sigma_{\mathrm{I}}-\sigma_{3}$ at the peak of the stress-strain curve (i.e. at the time of failure of the specimen), for various confining pressures $\sigma_{3}$. The maximum deviatoric stress increased linearly with increasing pressure to about $4^{0} \mathrm{MPa}$; with further increase in confining pressure, deviatoric stress dropped.

4. The initial tangent modulus $E_{\mathrm{i}}$ calculated from the linear portion of the stress-strain curves shown in Figure 3 varied between $\mathrm{I} 250$ and $2000 \mathrm{MPa}$. This value is somewhat smaller than the value of $E_{\mathrm{i}}$ calculated from unconfined compression tests at $-10^{\circ} \mathrm{C}$, namely $2500 \mathrm{MPa}$ (Parameswaran, 1980). The modulus seemed to decrease with increasing hydrostatic pressure.
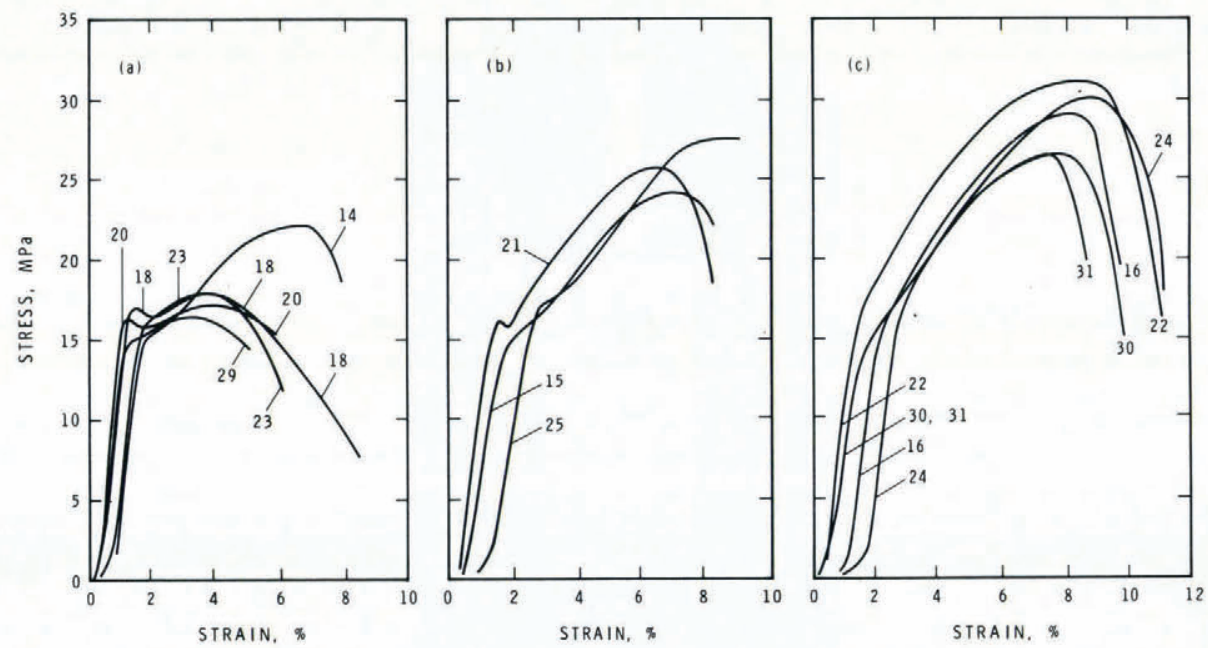

Fig. 3. Stress-strain curves of frozen sand under various confining pressures (see Table I for pressures corresponding to each curve).

* Strictly speaking, there is no true elastic behaviour in frozen soils as observed in metals. The early linear portion of the stress-strain curve is termed "elastic" here. 


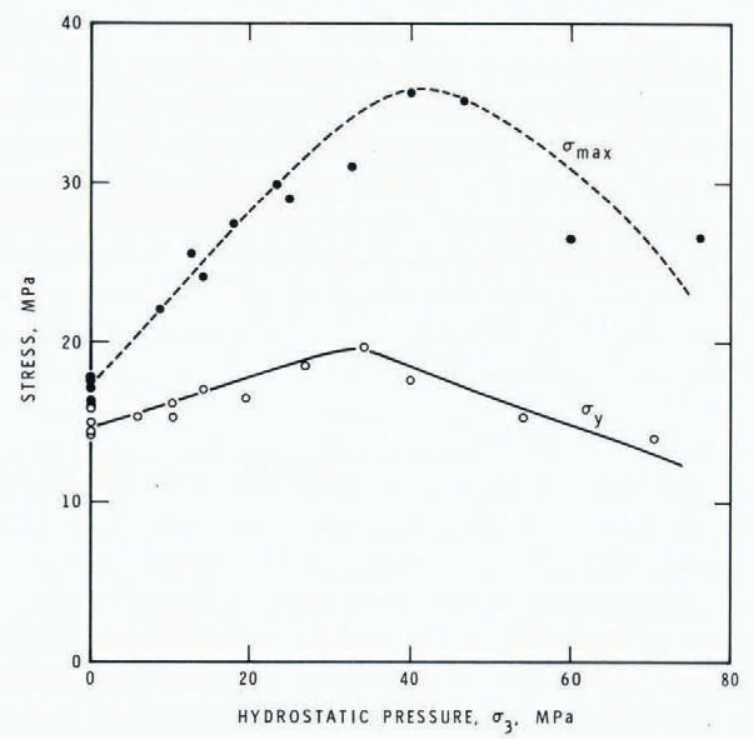

Fig. 4. Variation of yield stress $\sigma_{\mathrm{y}}$, and failure stress, $\sigma_{\max }=\left(\sigma_{1}-\sigma_{3}\right)$, with hydrostatic confining pressure.

TABLE I. VALUES OF STRESSES AND MODULI FOR FROZEN SAND

$$
\tau=10.1^{\circ} \pm 0.6^{\circ} \mathrm{C}, \dot{\epsilon}=7.7 \times 10^{-} \dot{\epsilon}: \mathrm{s}^{-1}
$$

\begin{tabular}{|c|c|c|c|c|c|c|c|}
\hline $\begin{array}{l}\text { Test } \\
\text { No. }\end{array}$ & $\begin{array}{c}\text { Yield } \\
\text { stress, } \\
\sigma_{\mathrm{y}} \\
\mathrm{MPa}\end{array}$ & $\begin{array}{c}\text { Hydrostatic } \\
\text { pressure } \\
\text { at } \sigma_{\mathrm{y}} \\
\mathrm{MPa}\end{array}$ & $\begin{array}{c}\text { Maximum } \\
\text { deviatoric } \\
\text { stress, } \\
\left(\sigma_{1}-\sigma_{3}\right)= \\
\sigma_{\max } \\
\mathrm{MPa}\end{array}$ & $\begin{array}{c}\text { Hydrostatic } \\
\text { pressure } \\
\text { at } \sigma_{\max }, \\
\sigma_{3} \\
\mathrm{MPa}\end{array}$ & $\begin{array}{c}\left(\sigma_{1}-\sigma_{3}\right) / 2 \\
\mathrm{MPa}\end{array}$ & $\begin{array}{c}\left(\sigma_{1}+\sigma_{3}\right) / 2 \\
\mathrm{MPa}\end{array}$ & $\begin{array}{c}\text { Initial } \\
\text { tangent } \\
\text { modulus } \\
E_{\mathrm{i}} \\
\mathrm{MPa}\end{array}$ \\
\hline 14 & I5.3 & $5 \cdot 5$ & 22.05 & 8.5 & I 1.025 & I $9.5^{25}$ & I 667 \\
\hline I5 & I $5 \cdot 3$ & I I.I & 24.09 & 14.0 & I 2.045 & 26.045 & I 333 \\
\hline 16 & 10.95 & 21.5 & 28.96 & 25.0 & I $4.4^{8}$ & $39 \cdot 4^{8}$ & I 429 \\
\hline 17 & I 4.35 & 0.1 & I 7.84 & 0.1 & $8.9^{2}$ & 9.02 & - \\
\hline 18 & $16.8 \mathrm{I}$ & 0.1 & 17.66 & 0.1 & 8.83 & 8.93 & I 765 \\
\hline 20 & I 6.30 & 0.1 & 17.13 & 0.1 & 8.565 & 8.665 & 2000 \\
\hline $2 \mathrm{I}$ & I6. 15 & Io & $25 \cdot 5^{8}$ & 12.5 & 12.79 & 25.49 & I 613 \\
\hline 22 & I8.5I & 27 & 30.95 & 32.5 & I 5.475 & $47 \cdot 975$ & 1702 \\
\hline 23 & I5.87 & 0.1 & 17.86 & 0.22 & 8.93 & $9 \cdot 15$ & I 563 \\
\hline 24 & I6.45 & I9.5 & $29.9^{\circ}$ & 23.4 & I 4.95 & $3^{8.35}$ & I 429 \\
\hline 25 & I 7.06 & 14.0 & 27.43 & 18.0 & 13.72 & $31 \cdot 72$ & I 250 \\
\hline 26 & 14.25 & O. I & I6. I 4 & 0.1 & 8.07 & 8.1 7 & - \\
\hline 29 & I 4.93 & O.I & I6. $3^{8}$ & 0.1 & 8.19 & 8.29 & I $75^{\circ}$ \\
\hline 30 & I 5.29 & $54 \cdot 3$ & 26.45 & $59 \cdot 5$ & 13.23 & 72.73 & I 400 \\
\hline $3^{I}$ & I 3.95 & 70 & $26.4^{8}$ & $75 \cdot 7$ & 13.24 & 88.94 & I 400 \\
\hline $3^{2}$ & I 7.66 & $39 \cdot 5$ & 35.14 & 47.5 & 17.57 & 65.07 & 一 \\
\hline 33 & I9.68 & 33.8 & 35.60 & 40.0 & 17.80 & 57.80 & \\
\hline
\end{tabular}

\section{Discussion}

The present experiments show that, in frozen sand, initial yield strength increases with increasing confining pressure up to about $34 \mathrm{MPa}$, as in polycrystalline ice (Jones, I978). This indicates that deformation behaviour in the early elastic region is governed mainly by the ice matrix. The elastic region, however, is not due solely to the ice matrix, as suggested by Sayles (1974), but represents the behaviour of ice modified by sand grains. The maximum yield stress observed for ice by Jones ( 1978 ) was $7.5 \mathrm{MPa}$ at a confining pressure of $30 \mathrm{MPa}$, whereas the value of the maximum yield stress in frozen sand observed in the present tests was 
19.7 $\mathrm{MPa}$ at a confining pressure of $34 \mathrm{MPa}$. The larger value of yield strength for frozen sand as compared to ice is due to the mobilization of soil grain friction, in addition to cohesion of ice. As in ice, initial increase in yield stress with pressure can be explained by closure of voids in the sand-ice specimens, thereby allowing the ice matrix to deform plastically. The decrease in yield stress beyond $34 \mathrm{MPa}$ may be associated with increasing unfrozen water round the sand grains, caused by hydrostatic pressure.

There seems to be a decrease in the modulus due to confining pressure. Such a decrease in modulus due to hydrostatic pressure has been observed in Solenhofen limestone (Paterson, I964) and in beryllium single crystals (Damiano and others, I969), but in polymers the modulus was increased considerably with superimposed hydrostatic pressure (see review article by Parry and Tabor, 1973). For most metals tested, such as copper, aluminium, cast iron, zinc, etc., no significant change has been observed in the early part of the stress-strain curve due to hydrostatic pressure (Brandes, I971).

The increase in failure strength due to increasing confining pressure can be analysed conveniently by considering the Mohr's rupture diagram and Coulomb's criterion for failure commonly known as the Mohr-Coulomb criterion. Soils, like most solid visco-elastic materials, fail in shear under compressive stress. Shear failure starts at a point in the mass of the soil when, on some surface passing through the point, a critical combination of shear and normal stresses is reached. In the triaxial compression tests now reported the major principal stress $\sigma_{I}$ acts vertically downwards and the cell pressure $\sigma_{3}$ represents both intermediate and minor principal stresses. With the maximum and minimum principal stresses a "Mohr-circle of stress" can be drawn with diameter equal to the deviatoric stress $\left(\sigma_{1}-\sigma_{3}\right)$ having its centre located along the abscissa at a distance of $\left(\sigma_{1}+\sigma_{3}\right) / 2$. In such a diagram the vertical axis represents the shear stress $\tau=\left(\sigma_{1}-\sigma_{3}\right) / 2$.

In a series of triaxial tests at least one point on each of the Mohr-circles of stress should represent the normal and shearing stresses $\sigma$ and $\tau$ associated with failure; thus the envelope of the failure circles represents the locus of points associated with failure of specimens. This envelope represents the rupture line for the given material. Figure 5 shows the Mohr-circles and the rupture line for saturated frozen sand. The rupture line for confining pressures up to about $32 \mathrm{MPa}$ follows the Coulomb equation:

$$
\tau=C+\sigma \tan \phi
$$

where $\tau$ is the shearing resistance or shear strength, and $\sigma$ is the normal stress at failure; $C$ is called cohesion, i.e. the cohesive strength at zero hydrostatic pressure, and $\phi$ is called the angle of internal soil-grain friction. Values of $C$ and $\phi$ for frozen sand from Figure 6 are $C \approx 7 \cdot 4 \mathrm{MPa}$ and $\phi \approx 12.7^{\circ}$, respectively.

Figure 6 shows the shear stress plotted against normal stress in a convenient form, i.e. the variation of $\left(\sigma_{\mathrm{I}}-\sigma_{3}\right) / 2$ with $\left(\sigma_{\mathrm{I}}+\sigma_{3}\right) / 2$. The straight line passing through the points follows an equation

$$
\frac{\left(\sigma_{1}-\sigma_{3}\right)}{2}=a+\frac{\sigma_{1}+\sigma_{3}}{2} \tan \alpha,
$$

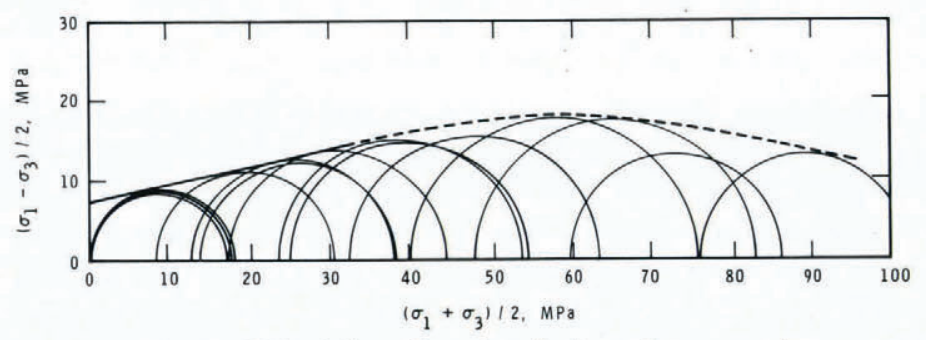

Fig. 5. Mohr-circles and envelope for frozen Ottawa sand. 


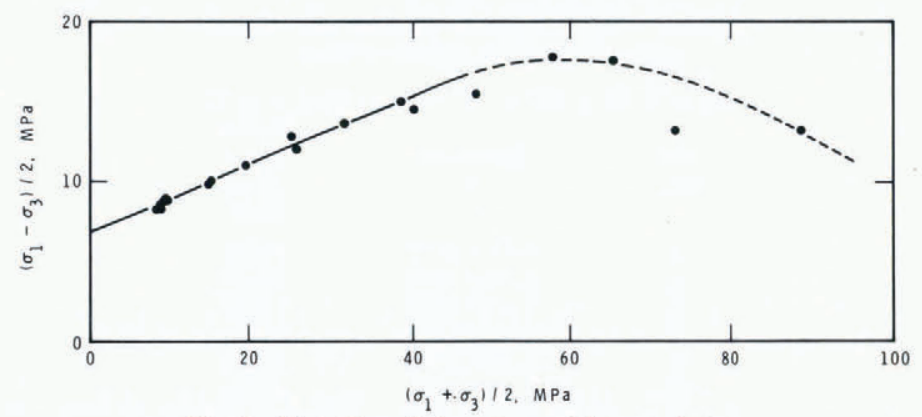

Fig. 6. Variation of shear stress with normal stress.

where the angle $\alpha$ is related to the angle of internal soil grain friction $\phi$ by the relation:

$$
\sin \phi=\tan \alpha,
$$

and the intercept $a$ is given by

$$
a=C \cos \phi .
$$

Equations (3) and (4) are derived from the geometrical relation of the Mohr-circles and their common tangent (for details see Terzaghi and Peck, I968).

From Figure 6 the values for $a$ and $\tan \alpha$ are 6.8 and 0.2133 , respectively, from which values of $C$ and $\phi$ calculated by Equations (3) and (4) are $C=7 \mathrm{MPa}$ and $\phi=12.4^{\circ}$. These values are very close to the values measured on the common tangent of the Mohr-circles shown in Figure 5, namely $7.4 \mathrm{MPa}$ and $12.7^{\circ}$. Owing to the uncertainty in the common tangent, which may not touch all the circles in Figure 5, the values of $C$ and $\phi$ obtained from Figure 6 are more accurate than those from Figure 5 .

\begin{tabular}{|c|c|c|c|c|}
\hline Reference & $\begin{array}{c}\text { Cohesion } \\
C \\
\mathrm{MPa}\end{array}$ & $\begin{array}{c}\text { Angle of } \\
\text { friction } \\
\phi \\
\text { deg }\end{array}$ & $\begin{array}{l}\text { Grain } \\
\text { size of } \\
\text { sand used } \\
\mathrm{mm}\end{array}$ & $\begin{array}{c}\text { Temperature } \\
T \\
{ }^{\circ} \mathrm{C}\end{array}$ \\
\hline in and others (1972) & $6.9 \mathrm{I}$ & 19.3 & $0.074-0.149$ & -10 \\
\hline Andersladn (1973) & 2.5 & 31.4 & $0.59-0.84$ & -12 \\
\hline 4) & $\approx 2.0$ & 30 & $0.59-0.84$ & -3.85 \\
\hline ly & 7.0 & I 2.4 & $0.2-0.6$ & -10 \\
\hline
\end{tabular}

TABle II. Values of cohesion $C$ And Angle of Friction $\phi$, obtained by Different authors

Thus, from the present set of experiments the value of cohesion for frozen saturated sand is about $7 \mathrm{MPa}$ and the angle of internal soil-grain friction is $12.4^{\circ}$. Table II shows thevalues under discussion as well as those for $C$ and $\phi$ obtained by previous authors. The value of $\phi$ now reported is much smaller than those reported by Alkire and Andersland (1973) or Sayles (1974), but it is close to the value obtained by Chamberlain and others (1972). The highest pressures at which Alkire and Andersland or Sayles tested their samples were 7 and 8.2 $\mathrm{MPa}$, respectively. As may be seen from Figures 4 and 6, one could draw a line with a steeper slope for confining pressures between 2 and $8 \mathrm{MPa}$ and thus obtain a larger value of $\phi$. Chamberlain and others (1972) tested their samples at pressures up to $280 \mathrm{MPa}$ and their values of $C$ and $\phi$ are closer to the present ones. The soil grain-size in their samples was much finer, however, and this could cause a difference in the value of the angle of internal friction $\phi$. The present value of $C$ agrees closely with that of Chamberlain and others (1972), but the values of $C$ obtained by Alkire and Andersland (1973) and by Sayles (1974) are much smaller. For unfrozen sand, Alkire and Andersland (1973) quote a value of $\phi$ of $37^{\circ}$. 


\begin{tabular}{|c|c|c|}
\hline \multicolumn{3}{|c|}{$\sigma_{3}=P \approx 5 \mathrm{MPa}, \quad T=-11.65 \pm 1.45^{\circ} \mathrm{C}$} \\
\hline $\begin{array}{l}\text { Test } \\
\text { No. }\end{array}$ & $\begin{array}{c}\text { Strain-rate } \\
\dot{\epsilon} \\
\mathrm{s}^{-\mathbf{1}}\end{array}$ & $\begin{array}{l}\text { stress } \\
\sigma_{\max } \\
\mathrm{MPa}\end{array}$ \\
\hline 3 & $7.8 \mathrm{I} \times 10^{-5}$ & 19.67 \\
\hline 4 & $3.12 \times 10^{-5}$ & 18.47 \\
\hline 5 & $1.54 \times 10^{-5}$ & 12.29 \\
\hline 6 & $7.71 \times 10^{-6}$ & 14.27 \\
\hline 7 & $1.55 \times 10^{-5}$ & 13.48 \\
\hline 8 & $1.54 \times 10^{-4}$ & 19.75 \\
\hline 9 & $3.08 \times 10^{-4}$ & 24.05 \\
\hline 10 & $7.72 \times 10^{-4}$ & 26.17 \\
\hline I I & $3.08 \times 10^{-4}$ & 20.05 \\
\hline 12 & $1.54 \times 10^{-3}$ & 21.33 \\
\hline I3 & $3.08 \times 10^{-3}$ & $26.6 \mathrm{o}$ \\
\hline
\end{tabular}

A few tests were carried out at a confining pressure of about $5 \mathrm{MPa}$ to study the effect of strain-rate on the strength of frozen sand. The average temperature for these tests was I I. $65 \pm \mathrm{r} .45^{\circ} \mathrm{C}$. Table III shows the values of the strength at different strain rates, and Figure 7 shows the variation of $\left(\sigma_{1}-\sigma_{3}\right)\left(=\sigma_{\max }\right)$ as a function of strain-rate $\dot{\epsilon}$ on a double logarithmic plot. Strength seems to vary according to an equation of the type

$$
\epsilon \propto \sigma_{\max }{ }^{12.5} \text {. }
$$

A similar equation with a value of the exponent equal to ro was observed by Sayles (1974) at $-3.85^{\circ} \mathrm{C}$, whereas Parameswaran (1980) obtained a value of 14.14 for the exponent from unconfined uniaxial compression tests at $-10^{\circ} \mathrm{C}$ on the same type of specimens as those used in the present experiments.

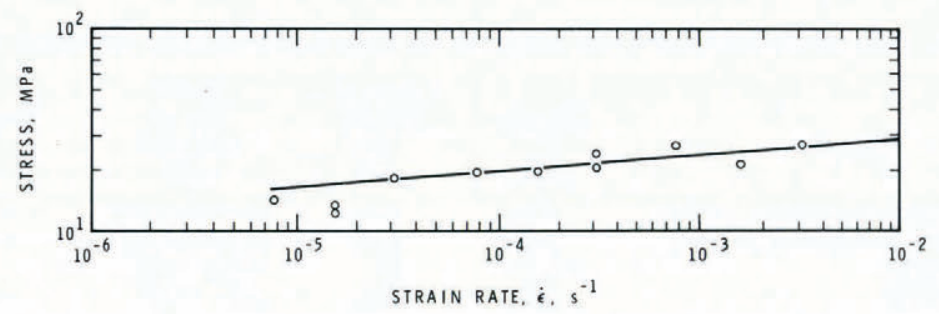

Fig. 7. Variation of failure stress, $\sigma_{\max }=\left(\sigma_{1}-\sigma_{3}\right)_{\max }$, with strain-rate $\dot{\epsilon}$ at a pressure of $5 \mathrm{MPa}$.

\section{Conclusion}

The yield strength of frozen, saturated Ottawa sand of uniform grain size containing about $20 \%$ by weight of water was found to increase with increasing hydrostatic confining pressure to about $34 \mathrm{MPa}$, then to decrease with further increase in pressure. The maximum value observed was $19.7 \mathrm{MPa}$ at a confining pressure of $34 \mathrm{MPa}$. Hydrostatic pressure suppresses the yield drop. Both flow stress and maximum failure stress (strength of the material) increase with increasing hydrostatic pressure to about $40 \mathrm{MPa}$, but the rate of increase is not so large as has been observed by other workers in frozen and unfrozen soil. For confining pressures larger than $40 \mathrm{MPa}$ the failure stress decreases. The initial increase in strength (yield and failure) with increasing hydrostatic confining pressure could be due to closure of voids and microcracks, allowing the ice to undergo plastic deformation. Decrease in strength after the maximum in Figure 4 with further increase in confining pressure is probably due to the increasing amount of unfrozen water in the samples as a result of pressure melting. 
The angle of internal soil-grain friction measured in the present experiments was only about $12.4^{\circ}$, whereas the corresponding value for unfrozen sand reported in the literature was $37^{\circ}$. The initial tangent modulus decreases with increasing confining pressure, presumably owing to pressure-melting of ice.

\section{Acknowledgement}

The authors wish to thank G. Mould and C. Hubbs of the Division of Building Research, National Research Council of Canada, for preparing the frozen soil specimens.

This paper is a contribution from the Division of Building Research, National Research Council of Canada, and is published with the approval of the Director of the Division.

MS. received I October 1979

\section{REFERENCES}

Alkire, B. D., and Andersland, O. B. 1973. The effect of confining pressure on the mechanical properties of sand-ice materials. Fournal of Glaciology, Vol. 12, No. 66, p. 469-81.

Andersland, O. B., and Akili, W. 1967. Stress effect on creep rates of a frozen clay soil. Géotechnique (London), Vol. 17 , No. I, p. 27-39.

Andersland, O. B., and AlNouri, I. 1970. Time-dependent strength behavior of frozen soils. Fournal of the Soil Mechanics and Foundation Division, American Society of Civil Engineers, Vol. 96, No. SM4, p. $1249-68$.

Baker, T. H. W. ${ }^{1976}$. Preparation of artificially frozen sand specimens. Canada. National Research Council. Division of Building Research. Paper No. 682.

Brandes, M. I971. Mechanical properties of materials under hydrostatic pressure. (In Pugh, H. L. D., ed. The mechanical behaviour of materials under pressure. London, Allied Science Publishers Ltd., p. 236-98.)

Chamberlain, E., and others. 1972. The mechanical behaviour of frozen earth materials under high pressure triaxial test conditions, by E. Chamberlain, C. Groves, and R. Perham. Géotechnique (London), Vol. 22, No. 3 , p. $469-83$.

Damiano, V. V., and others. 1969. Deformation of beryllium single crystals under high pressure, by V. V. Damiano, J. E. Hanafee, G. J. London, and N. Inoue. Transactions of the Metlalurgical Society of the AIME, Vol. 245, No. 4, p. 637-49.

Goughnour, R. R., and Andersland, O. B. 1968. Mechanical properties of a sand-ice system. Fournal of the Soil Mechanics and Foundations Division, American Society of Civil Engineers, Vol. 94, No. SM4, p. 923-50.

Jones, S. J. 1978. Triaxial testing of polycrystalline ice. Proceedings of the third International Conference on Permafrost, July 10-13, 1978, Edmonton, Alberta, Canada, Vol. 1, p. 670-74.

Kaplar, C. W. 1971. Some strength properties of frozen soils and effect of loading rate. U.S. Cold Regions Research and Engineering Laboratory. Special Report 159.

Parameswaran, V. R. 1980. Deformation behaviour and strength of frozen sand. Canadian Geotechnical Journal, Vol. 17 , No. 1, p. 74-88.

Parry, E. J., and Tabor, D. r 973 . Effect of hydrostatic pressure on the mechanical properties of polymers: a brief review of published data. Fournal of Materials Science, Vol. 8, No. 10, p. $1510-16$.

Paterson, M. S. 1964. Triaxial testing of materials at pressures up to $10,000 \mathrm{~kg} / \mathrm{sq} \mathrm{cm}$. Journal of the Institution of Engineers, Australia, Vol. 36, Nos. 1-2, p. 23-29.

Perkins, T. K., and Ruedrich, R. A. 1973. The mechanical behaviour of synthetic permafrost. Society of Petroleum Engineers fournal, Vol. 13, No. 4, p. $211-20$.

[Permafrost.] [1966.] Proceedings. Permafrost International Conference, II-15 November I963, Lafayette, Indiana. - Presented by Building Research Advisory Board, National Academy of Sciences-National Research Council, Washington, D.C., at Purdue University. Washington, D.C. National Academy of Sciences-National Research Council. (Publication No. 1287.)

[Permafrost.] 1973. Permafrost. Second International Conference. 13-28 July 1973, Yakutsk, U.S.S.R. North American contribution. Washington, D.C. National Academy of Sciences.

[Permafrost.] 1978. Proceedings of the third International Conference on Permafrost, July 10-13, 1978, Edmonton, Alberta, Canada. Vol. I. Ottawa, National Research Council of Canada.

Ruedrich, R. A., and Perkins, T. K. 1974. A study of factors influencing the mechanical properties of deep permafrost. Fournal of Petroleum Technology, Vol. 26, No. 10, p. i $167-77$.

Sayles, F. H. 1974. Triaxial constant strain rate tests and triaxial creep tests on frozen Ottawa sand. U.S. Cold Regions Research and Engineering Laboratory. Technical Report 253.

Terzaghi, K., and Peck, R. B. 1968 . Soil mechanics in engineering practice. New York, John Wiley and Sons, Inc. 